\title{
The level of C.pneumoniae, Cytomegalovirus, and H.pylori antibody in a patient with coronary heart disease
}

Dasnan Ismail

\begin{abstract}
Abstrak
Aterosklerosis sampai saat ini merupakan penyebab utama morbiditas dan mortalitas di negara maju. Meskipun modifikasi faktor risiko di negara maju telah dapat menurunkan kekerapan aterosklerosis namun penurunan ini mulai menunjukkan grafik yang mendatar. Keadaan ini merangsang para peneliti untuk mencari faktor pajanan lingkungan termasuk faktor infeksi yang dapat mempengaruhi proses aterosklerosis. Telah dilakukan penelitian potong lintang dari bulan Maret 1998 sampai Agustus 1998 terhadap 122 orang pasien yang secara klinis menunjukkan penyakit jantung koroner yang menjalani kateterisasi jantung, terdiri dari 92 orang laki-laki dan 30 orang perempuan dengan rerata umur 55 tahun. Pasien diperiksa secara klinis dan laboratorium (gula darah, kolesterol, trigliserida dan antibodi terhadap C.pneumoniae, Cytomegalovirus dan H.pylori). Pada penelitian ini didapatkan perbedaan kadar kolesterol, trigliserida dan HDL antara kelompok stenosis koroner dan non stenosis. Sedangkan kadar antibodi C.pneumoniae, Cytomegalovirus, H.pylori tidak berbeda bermakna. Penelitian ini belum dapat menyimpulkan pengaruh antibodi terhadap aterosklerosis karena pada kelompok non stenosis tidak dapat disingkirkan kemungkinan terjadinya aterosklerosis mengingat rerata umur subyek penelitian 55 tahun. Penelitian mengenai interaksi infeksi dengan risiko tradisional serta gender dan nutrisi diperlukan untuk mendapat jawaban yang lebih jelas tentang pengaruh infeksi terhadap aterosklerosis. (Med J Indones 2002; 11: 211-4)
\end{abstract}

\begin{abstract}
Atherosclerosis is still the chief cause of morbidity and mortality in developed nations. Even though in developed nations the modification of risk factors is able to reduce the prevalence rate of atherosclerosis, such reduction is starting to slow down. Such condition has stimulated researchers to identify environmental exposure, including infection, that can influence the process of atherosclerosis. This cross sectional study was conducted from March to August 1998, on 122 patients that clinically demonstrate coronary heart disease and have underwent cardiac catheterization, 92 males and 30 females with an average age of 55 years. Patients undergo clinical and laboratory evaluation (blood glucose, cholesterol, triglyceride, and antibody for C.pneumoniae. Cytomegalovirus, and H.pylori). We found a significant difference in cholesterol, triglyceride, and HDL levels in those with coronary stenosis and those without. However, we did not find a significant difference in the levels of C.pneumoniae, Cytomegalovirus, and H.pylori antibodies. This study is unable to conclude the influence of these antibodies on atherosclerosis, since in the non-stenosis group, we cannot eliminate the possibility of atherosclerosis, since the average age of study subject is 55 years. Studies on the interaction between infection and traditional risk factors as well as gender and nutrition is needed to find a clear answer of the influence of infection in atherosclerosis. (Med J Indones 2002; 11: 211-4)
\end{abstract}

Keywords: Level of C.pneumoniae, Cytomegalovirus, H.pylori antibody, coronary heart disease.

Atherosclerosis is still the chief cause of morbidity and mortality in developed nations. In Indonesia, even though infectious disease is still the chief health problem, degenerative disease, including atherosclerosis, has become an important health problem. The most recent development and management of coronary heart disease, both in reducing risk factors, establishing a diagnosis, and intervention is still unsatisfactory. Surgical intervention requires complete facilities at high costs. Even though in developed

Department of Internal Medicine, Faculty of Medicine University of Indonesia/Dr. Cipto Mangunkusumo National Centre Hospital, Jakarta, Indonesia nations the modification of risk factors is already able to peduce the prevalence rate of atherosclerosis, such reduction is starting to slow down. ${ }^{1-3}$ Such condition has stimulated researchers to identify environmental exposures including infection, that can influence the process of atherosclerosis. ${ }^{4-6}$ Sero-epidemiological and pathological studies as well as laboratory animal studies and clinical data demonstrate that chronic infection by C.pneumoniae, Cytomegalovirus, and H.pylori may play a role in the pathogenesis of atherosclerosis. Even though there has been many studies associated with the process of atherosclerosis, the exact relationship between atherosclerosis and infection is still unclear. 
Meta analysis demonstrated a relationship between an increase in C.pneumoniae antibody and the prevalence of coronary heart disease. ${ }^{7}$ Saiko first reported a case control study in post-acute myocardiac infarction and chronic coronary heart disease that demonstrated an increase in pneumoniae antibody compared to control subjects. ${ }^{8}$ Shor first reported C.pneumoniae in atherosclerosis lesion under the electron microscope. ${ }^{9}$

Ramirez found that C.pneumoniae can be cultured from atherosclerotic plaques. ${ }^{10}$

Cytomegalovirus is associated with primary atherosclerosis, post angioplasty re-stenosis and post-transplantation atherosclerosis. On the other hand, the association of H.pylori and atherogenesis is not as strong as the relationship between C.pneumoniae or CMV. ${ }^{7,11}$

In Indonesia, examinations for C.pneumoniae, CMV and H.pylori antibody associated with coronary heart disease has not been frequently reported.

\section{METHODS}

This study is a cross sectional study on patients that clinically demonstrate coronary heart disease and undergo cardiac catheterization. This study was conducted from March to August 1998. All study subjects that met the criteria were incorporated in the study (consecutive sampling) after stating informed consent. Patients that underwent cardiac catheterization undergo clinical and laboratory evaluation (blood glucose, cholesterol, triglyceride, and antibody for C.pneumoniae, Cytomegalovirus, and H.pylori). Evaluation for C.pneumoniae, cytomegalovirus, and H.pylori antibody were performed using the Elisa method. The statistical analysis used was the t-test and logistic regression.

\section{RESULTS}

There were 122 an study subjects that participated in this study. Most of the study subjects were male with an average age of 55 years. There were more non- smokers than smokers. The initial data of the patients in this study can be found in Table 1 .

Table 1. Baseline characteristics of study subjects $(n=122)$

\begin{tabular}{lc}
\hline Age (years) & $55.03 \pm 10.65$ \\
Sex & $92(75.4 \%)$ \\
$\quad$ Male & $30(24.6 \%)$ \\
Female & $51(41.8 \%)$ \\
Smoking & $71(58.2 \%)$ \\
$\quad$ Yes & \\
No & $62(50.8 \%)$ \\
History of hypertension & $60(49.2 \%)$ \\
Yes & $201.68 \pm 42.25$ \\
No & $41.10 \pm 10.93$ \\
Total cholesterol level & $191.27 \pm 91.55$ \\
HDL cholesterol & $137.89 \pm 56.35$ \\
Triglyceride & $340.36 \pm 105.97$ \\
Blood sugar & $1.63 \pm 0.69$ \\
Fibrinogen & $2.88 \pm 2.26$ \\
C.pneumoniae & $32.35 \pm 10.07$ \\
Cytomegalovirus & \\
H.pylori &
\end{tabular}

The group with coronary stenosis compared to those without coronary stenosis did not demonstrate a significant difference in cholesterol and triglyceride level, as seen in Table 2.

Table 2. The difference between groups with coronary stenosis and those without

\begin{tabular}{lccc}
\hline Criteria & $\begin{array}{c}\text { Coronary stenosis } \\
(\mathrm{n}=83)\end{array}$ & $\begin{array}{c}\text { No coronary } \\
\text { stenosis }(\mathrm{n}=39)\end{array}$ & $\mathrm{P}$ \\
\hline Age (years) & $56.18 \pm 9.60$ & $52.58 \pm 13.19$ & 0.09 \\
Blood sugar & $135.90 \pm 56.35$ & $142.12 \pm 56.37$ & 0.572 \\
Total cholesterol & $206.15 \pm 43.29$ & $192.17 \pm 77$ & 0.088 \\
Triglyceride & $204.08 \pm 95.55$ & $164.02 \pm 76.57$ & 0.024 \\
HDL & $39.65 \pm 10.74$ & $44.02 \pm 10.83$ & 0.031 \\
LDL & $126.59 \pm 40.34$ & $115.15 \pm 35.42$ & 0.132 \\
Fibrinogen & $351.86 \pm 117.94$ & $315.87 \pm 69.54$ & 0.080 \\
\hline
\end{tabular}

There was no significant difference in the antibody levels in groups with stenosis and without, as seen in Table 3. 
Table 3. The difference in the antibody levels in the group of patients with and without stenosis

\begin{tabular}{lccc}
\hline Criteria & $\begin{array}{c}\text { Coronary stenosis } \\
(\mathrm{n}=83)\end{array}$ & $\begin{array}{c}\text { No coronary } \\
\text { stenosis }(\mathrm{n}=39)\end{array}$ & $\mathrm{P}$ \\
\hline C.pneumoniae & $1.6233 \pm 0.7200$ & $1.6533 \pm 0.6292$ & 0.812 \\
CMV & $2.8217 \pm 2.2835$ & $3.0179 \pm 1.9896$ & 0.656 \\
H.pylori & $38.3133 \pm 118.6253$ & $19.6487 \pm 35.7222$ & 0.339 \\
\hline
\end{tabular}

\section{DISCUSSION}

This study is a cross-sectional study. Evaluation of the levels of C.pneumoniae, CMV, and H.pylori antibodies was conducted prior to heart catheterization examination. C.pneumoniae, CMV, and H.pylori antibodies was evaluated by the evaluation of $\mathrm{IgG}$ antibodies evaluation, signifying past infection. In this study, we were not able to demonstrate a significant difference in the anti- C.pneumoniae, CMV, and H.pylori IgG levels in groups with and without stenosis. Even though this group was classified into those with coronary stenosis and those without, it does not mean that those in the group without stenosis did not suffer from atherosclerosis. Coronary stenosis is an advanced stage of the atherosclerotic process.

Proof that associated C.pneumoniae infection and atherosclerosis was conducted sero-epidemiologically, through direct detection of bacterial components in the atherosclerotic lesion and isolation of the bacteria from carotid and coronary atherome tissue. Many seroepidemiological studies have associated increased C.pneumoniae serology with myocardial infarction, coronary heart disease, and stroke. Prospective studies that have been performed do not provide strong evidence that support a relationship between C.pneumoniae, cytomegalovirus, and H.pylori infection with coronary heart disease. In C.pneumoniae infection, the riskratio towards coronary heart disease is $1.22(95 \% \mathrm{CI}$ $0.96-1.54)$, the risk ratio for cytomegalovirus is 0.91 (95\%, CI 0.69-1.19), and the risk ratio for H.pylori is 1.13 (95\%, 0.93-1.38). ${ }^{12}$ Even though we must understand the diagnostic criteria, the limit of the titer used may be different. We also have to take into consideration the possibility of confounding factors such as smoking, and also the number of samples being studied. ${ }^{14}$ In addition, when performing the evaluation, we also need to consider the fact that over $50 \%$ adults have antibodies against C.pneumoniae. The evaluation of antibody levels should be conducted serially, since there is a tendency for re- infection, thus causing fluctuation of the antibody serum. ${ }^{12,13}$ Melnich reported that patients that undergo coronary bypass surgery have an increased CMV antibody of $70 \%$, compared to $43 \%$ in control subjects. ${ }^{14}$ Pathological studies using PCR for CMV found $57 \%$ in atherosclerotic plaques and $36 \%$ in control subjects. Zhou reported that CMV infection is a strong independent risk factor for the development of post-atherectomy re-stenosis. ${ }^{15}$ In patients positive for CMV, atherosclerosis of the graft occurs in $68.8 \%$ cases, while occurring in only $36.8 \%$ in patients with negative CMV. ${ }^{16}$ Mendal reported that patients with positive H.pylori serology, there is a twofold risk of coronary heart disease. ${ }^{17}$ Patel reported a correlation between H.pylori, C.pneumoniae, and coronary heart disease. ${ }^{18}$ Rathbone et al, reported no correlation between H.pylori and coronary heart disease. ${ }^{19}$

Paseri reported infection of a bacteria more virulent that Cag-A positive strain of H.pylori demonstrating a significant correlation with coronary heart disease. ${ }^{20}$ From the pathological evaluation of 50 patients with abdominal aortal aneurysm, the DNA of H.pylori was not found in the atherosclerosis plaque. ${ }^{7}$ The presence of microbes or their components in atherosclerotic lesions is estimated to be the initiating factor for the exacerbation of disease, but can not directly be concluded as the causative agent.

Influencing factors in the risk of coronary heart disease in this study was total cholesterol, HDL cholesterol, and triglyceride. This was in accordance with various studies that have taken place. It seems that infectious agents are not sufficient to cause atherosclerosis by themselves, but instead do so in conjunction with other risk factors for the development of atherosclerosis, such as smoking, hyperlipidemia, hypertension, etc.

Studies on human subjects, such as this one, are usually focused on advanced stages of atherosclerosis. Animal studies, on the other hand, are able to study earlier stages of the disease. Such condition needs to be understood, since the exposure to infection during childhood is common. In addition, available studies do not sufficiently consider past infection, whether it is active, persistent, recurrent, or latent. To be able to produce more reliable results, we need to conduct studies with serial antibody level evaluation of a larger number of samples, on homogenous population, with early onset of the disease. The Center for Disease Control and Prevention and Laboratory Center for Disease Control, which conducted a workshop in 
Canada, recommended to increase the reproducibility and comparability of C.pneumoniae studies. ${ }^{21-22}$

Studies conducted now a days are those that study the interaction between infection, traditional risk factors, and other determinants of host susceptibility, such as gender and nutrition.

\section{CONCLUSION}

In this study conducted on 122 people undergoing heart catheterization, we found a significant difference in cholesterol, triglyceride, and HDL levels between those with coronary stenosis and those without.

However, we did not find a significant difference in the levels of C.pneumoniae, CMV, and H.pylori antibodies. This study is unable to conclude the influence of these antibodies on atherosclerosis, since in the non-stenosis group, we cannot eliminate the possibility of atherosclerosis, since the average age of study subjects is 55 years. Studies on the interaction between infection and traditional risk factors as well as gender and nutrition is needed to find a clear answer of the influence of infection in atherosclerosis.

\section{Acknowledgement}

The author wishes to thank Prof. T. Santoso MD, PhD who performed coronary angiography procedure, and kindly shared his data, and gave critical advice in the preparation of the manuscript.

\section{REFERENCES}

1. Centers for Disease Control and Prevention. Achievements in public health, 1900-1999: Decline in deaths fom heart disease and stroke-United States, 19001999. Hyattsville (MD): US Dept. of Health and Human Services, Centers for Disease Control and Prevention; 1999.p.649-56.

2. American Heart Association. 2001 heart and stroke statistical update. Dallas (TX): American HeartAssociation 1; 2000.

3. Centers for Disease Control and Prevention. Chronic Disease Notes and Reports 1997; 10: 2-15.

4. Ross R. Atherosclerosis-an inflammatory disease. N Engl J Med 1999; 340: 115-26.

5. Gaydos CA, Quinn TC. The role of Chlamydia pneumoniae in cardiovascular disease. Ann Intern Med 200; 45: 139-73.
6. Muhlestein JB. Chronic infection and coronary artery disease. Med ClinNorth Am 2000; 84: 123-48.

7. Danesh J, Collins R, Peto R. Chronic infection and coronary heart disease: is there a link? Lancet 1997; 350:430-6.

8. Saikku P, Mattila KJ, Nieminen MS, Makela PH, Hatkinen JK, Valtonen V. Serological evidence of an association of novel chlamydia TWAR with chronic coronary heart disease and acute myocardial infarction. Lancet 1998;2: 983-6.

9. Shor A, Kuo CC, Patton DL. Detection of chlamydia pneumoniae in coronary arterial fatty streak and atheromatous plaques. S Afr Med J 1992; 82: 158-61.

10. Ramirez JA. Isolation of chlamydia pneumoniae atherosclerosis study group. Ann Intern Med 1996;27:1555-61.

11. Ridker PM, Hennekens CH, Buring JE, Kundsin R, Shih J. Baseline IgG antibody titers to Chlamydia pneumoniae, Helicobacter pylori, herpes simplex virus, and cytomegalovirus and the risk for cardiovascular disease in women. Ann Intern Med 1999; 131:573-7.

12. Danesh J. Coronary heart disease, Helicobacter pylori, dental disease, Chlamydia pneumoniae and cytomegalovirus: metaanalyses of prospective studies. Am Heart J 1999; 138:S434-7.

13. West R. Commentary: adjusment for potential confounders may have been taken too for. BMJ 2000; 312:213.

14. Melnick JL, Adam E, Debakey ME, Cytomegalovirus and atherosclerosis. Eur Heart J 1993; 14(Suppl K): 30-8.

15. Zhou Y, Leon M, Waclawiw M, Pompa J, Yu ZX, Finkel T, et al. Association between prior cytomegalovirus infection and the risk of restenosis after coronary atherectomy. N Engl J Med 1996;335:624-30.

16. Brattan MT, Moreno-Cabral CE, Starnes VA, Oyer PE, Stainson EB, Shumway NE. Cytomegalovirus infection is associated with cardiac allograft rejection and atherosclerosis. JAMA 1989;2161:3561-6.

17. Mendall MA, Goggin PM, Molineux N, Levy J, Toosy T, Strachan D, Northfirld TC. Childhood living conditions and Helicobacter pylori seropositivity in adult life. Lancet 1992; 339:896-7.

18. Patel P, Mendall MA, Carrington D, Strachan DP, Leathon E, Molineaux $\mathrm{N}$ et al. Association of Helicobacter pylori and Chlamydia pneumoniae infections with coronary heart disease and cardiovascular risk factors. BMJ 1995;3111: 711-4.

19. Rathbone B, Martin D, Stephens J, Thomson JR, Samani NJ. Helicobacter pylori seropositivity in subjects with acute myocardial infarction. Heart 1996;76:308-11.

20. Pasceri V, Cammarota G, Patti G, Cuoco L, Gasbarrini A, Grillo RL et al. Association of virulent Helicobacter pylori strain with ischaemic heart disease. Circulation 1998; 97:1675-9.

21. Peeling RW, Wang SP, Grayston JT, Blasi F, Boman J, Clad A, et al. Chlamydia pneumoniar serology: interlaboratory variation in microimmunofluorescence assay results, J Infect Dis 2000; 181 Suppl 3: 426-9.

22. Dowell SF, Peeling RW, Boman J, Carlone GM, Fields BS, Guarner J, et al. Standardizing Chlamydia pneumoniae assays: Prevention (USA) and the Laboratory Centre for Disease Control (Canada). Clin Infect Dist 2001.in press 